\title{
Special management aspects of farming pakihi
}

BRENT RILEY

Collingwood

I farm in partnership with Michelle, leasing a 218 ha dairy farm and adjoining 60 ha runoff in Collingwood, Western Golden Bay. We wintered 810 cows and 110 yearlings on the property which comprises $35 \%$ alluvial river flats and $65 \%$ pakihi.

We are also $20 \%$ shareholders in a family-owned company that operates four dairy farms, one of them being the farm that we lease, the other three being run by my two brothers and their families, and my parents. One of these we have visited at Matariki on the field trip.

We run a high stocking rate system of 3.6 cows/ha with high inputs and produced $245000 \mathrm{~kg}$ milksolids last season. We farm in a wet environment, although we do get some sunny days. So far this season we have had 110 inches of rain, up on the average of 100 inches. Fortunately, we live on the dry side of the valley!

I hope to give you an insight into farming pakihi; the process we went through to develop and establish pasture from scrub; and the changes that have occurred with time on this soil type.

\section{The pakihi soils}

The pakihi soils of Golden Bay originally carried little forest other than some yellow pine and white pine (kahikatea) swamps. It is open country, mainly swampy, the vegetation being umbrella fern, rushes and, on drier ground, manuka. Remnants of forest swamps can be found as buried logs well preserved in the acidic soils. Attempts in the early days to farm this land were unsuccessful. Little was known about fertiliser treatment for these soils and the main efforts were put into draining the land but with little success.

Pakihi soils are know as gley podzols. The type we farm is know as Onahau soil. The other type in Golden Bay is Kotinga. Onahau soils have about 3 inches of peaty topsoil on a compact fine sand subsoil, overlying a shallow iron pan. Most Onahau soils have a slight slope, giving good surface drainage.

\section{Developing and farming our pakihi land}

Development of pakihi land on our property started in the mid-1970s, continuing through the 1980s. This involved slashing the scrub with tractor and flails and drainage of wet areas. Often it was hard to tell how wet or stumpy some area were. Thicker areas of scrub and fern were often double slashed. Oversowing of seed was the way we developed our pakihi, sowing seed directly onto the slashed ground. This was a cheap way of developing land, as no cultivation was required. Fertiliser and lime were put on at the same time.

Initially, nutrient levels were very low, as pakihi has virtually no natural fertility. Phosphate levels of $2-$ 5 and potassium levels of $0-2$ give an indication of initial fertility. Sulphur and nitrogen were also very deficient.

Fives tonnes/ha of lime was spread, as the $\mathrm{pH}$ was often originally below 5.0. Pakihi Starter Mix at 800 $\mathrm{kg} /$ ha was used to "kick-start" the fertility. This brew had all the trace elements - $\mathrm{Cu}, \mathrm{Co}, \mathrm{Se}, \mathrm{B}, \mathrm{Zn}, \mathrm{Mo}-$ and also extra sulphur.

Generally, we developed our blocks in summer as it was then the ground was driest. Sowing was done in February or early March. First grazing was usually done in November, the following spring. By this time the second dressing of fertiliser of $500 \mathrm{~kg} / \mathrm{ha} 30 \%$ potassic super had been applied. Strong clover dominance in the first couple of years was normal.

Pasture species used then were Nui perennial ryegrass, Hui white clover, Pawera red clover, Wana cocksfoot and timothy.

Slashing of regrowth the following autumn was usually done after block grazing by heifers or dry cows.

Grass growth has been measured for some years now. Annual growth rates have been $12.5 \mathrm{t} / \mathrm{ha}$ on the pakihi and $14.5 \mathrm{t} / \mathrm{ha}$ on the alluvial riverflats.

During the late 1980s and early 1990s, we concentrated on working blocks of alluvial ground and developed the worst-performing areas first. One very swampy block we developed would now produce the best grass on the farm, growing about 17-18 t DM/ha.

More recent pasture species sown have been Yatsyn and Embassy ryegrasses and Kopu, Aran and Sustain white clover. In the last two seasons, Impact/Sustain mixes have been sown. All seem to perform very well.

Pakihi soils require high inputs of fertiliser and the benefits of high application for some years now have improved fertility greatly. Phosphorus levels on the pakihi now range from 15 to 35 and potassium levels from 4 to 7 . It is difficult and expensive to maintain 
these levels and we soil test the same paddocks annually.

This season our recommendations suggest:

184 units of $\mathrm{N}, 67$ of $\mathrm{P}, 137$ of $\mathrm{K}$, and 116

of $\mathrm{S}$ to be applied.

In recent years more high analysis fertilisers have been sown, lifting phosphorus levels. However, sulphur levels have been falling and this season some elemental sulphur will be added along with pakihi maintenance minerals.

Lime at $2.5 \mathrm{t} / \mathrm{ha}$ is applied every two years to maintain $\mathrm{pH}$.

With increased fertility and a deeper humus layer, the management of the pakihi in wet weather is becoming more difficult. When the soil was first developed, pugging was virtually non-existent. Cows could be left on paddocks in very wet weather, for example 6 inches of rain overnight, and no pugging would occur. Now wet weather management is crucial on many areas and wintering all cows at home won't be possible much longer. This past winter and spring have been quite wet and stock spent a lot of time standing off pasture, mainly on races. I think in time some off-grazing will be necessary in order to protect pastures.

During the last two years we have cultivated and levelled two yellow pine swamp blocks on the pakihi.
This involved ripping with a bulldozer and root-raking the stumps out onto the surface, then raking the stumps into windrows and carting them away with dumper trucks. There were far more stumps and logs underground than we expected and this was the only practical way to handle the quantity of timber. Initially, 15 years ago when we developed this area the same process of oversowing was used as outlined. This particular block was drained several years before sowing, as it was extremely wet. These drains have now been refilled and levelled over. Supplements could now be taken off this area. The cost of this second phase of development was about $\$ 2000 /$ ha, including fertiliser and lime. While quite expensive, it is very satisfying to see our poorest-performing areas becoming the most productive. It is also good to get out of the lowest gearbox when driving across it with the manure sower.

In conclusion, Golden Bay soils can be challenging to farm but they can be developed to a high level. High stocking rates help control the bursts of growth we get in October/November and control regrowth of natural vegetation (rushes and sedges) in early summer. I believe this, a sound fertiliser regime and protecting the soil from damage in winter are the "special management aspects" to farming pakihi soils. 